\title{
Oceanic nutrient supply and uptake by microphytobenthos of the Hichirippu Lagoon, Hokkaido, Japan
}

\author{
Tomohiro Komorita ${ }^{1,2, *}$, Hiroaki Tsutsumi ${ }^{2}$, Rumiko Kajihara ${ }^{1,3}$, Natsumi Suga ${ }^{1,4}$, \\ Seiichiro Shibanuma ${ }^{1}$, Toshiro Yamada ${ }^{5}$, Shigeru Montani ${ }^{1}$ \\ ${ }^{1}$ Graduate School of Environmental Science, Hokkaido University, N10W5, Kita-ku, Sapporo 060-0810, Japan \\ ${ }^{2}$ Faculty of Environmental and Symbiotic Science, Prefectural University of Kumamoto \\ Tsukide, Kumamoto 862-8502, Japan \\ ${ }^{3}$ National Research Institute of Fisheries Engineering 7620-7, Hasaki, Kamisu-shi, Ibaraki 314-0408, Japan \\ ${ }^{4}$ Center for Marine Environmental Studies, Ehime University, 2-5 Bunkyo-cho, Matsuyama, Ehime 790-8577, Japan \\ ${ }^{5}$ Nishimuragumi Co. Ltd., 133 Sakaemachi, Yubetsu, Monbetsu, Hokkaido 099-6404, Japan
}

\begin{abstract}
We conducted field surveys to determine spatio-temporal variations in the water quality (including inorganic nutrient concentration) of a coastal lagoon, Hichirippu Lagoon (3.56 $\mathrm{km}^{2}$ ), in Hokkaido, Japan. During a typical supply period (winter), a $24 \mathrm{~h}$ continuous survey was conducted to evaluate nutrient supply from the open ocean and examine nutrient utilization by microphytobenthos (MPB) based on the mass balance of a biophilic element. During February 2008 , the majority of $\mathrm{NO}_{3}+\mathrm{NO}_{2}-\mathrm{N}$ was supplied from the open ocean, and the dissolved inorganic nitrogen (DIN) budget was $3.25 \mathrm{kmol} \mathrm{N} \mathrm{d}^{-1}$. In March 2008, the total amount of organic nitrogen was 39.0 to $588 \mathrm{kmol} \mathrm{N}$ for MPB in the surface sediment (depth, $0.5 \mathrm{~cm}$ ). Assuming that MPB in the surface sediment used all $\mathrm{NO}_{3}+\mathrm{NO}_{2}-\mathrm{N}$ input $\left(3.93 \mathrm{kmol} \mathrm{N} \mathrm{d}{ }^{-1}\right.$ ), their temporal division rate $\left(\mathrm{NO}_{3}+\mathrm{NO}_{2}-\mathrm{N}\right.$ uptake/total amount of MPB) would be 0.01 to $0.10 \mathrm{~d}^{-1}$. Here the annual DIN budget was estimated to be $258 \mathrm{kmol} \mathrm{N} \mathrm{yr}^{-1}$, which mainly depended on MPB-fixed oceanic DIN during winter.
\end{abstract}

KEY WORDS: Microphytobenthos $\cdot$ Coastal ecosystem $\cdot$ Nutrient cycles $\cdot$ Dissolved inorganic nutrients $\cdot$ Mass balance

\section{INTRODUCTION}

Coastal lagoons occupy $13 \%$ of the world's coastline and are among the most common coastal environments (Kjerfve 1986). Their productivity makes them major fishing areas. A coastal lagoon system is mainly considered a river-dominated system that is easily affected by anthropogenic eutrophication (Knoppers et al. 1991, Nedwell et al. 1999, Kemp et al. 2005). The coastal lagoon system of Ohuira Lagoon, northwestern Mexico, changed repeatedly between estuarine-marine and estuarine-terrestrial environments because of human activity (Ruiz-Fernández et al. 2007), and that of Nakaumi Lagoon, southwestern Japan, was eutrophicated by several factors, including increased nutrient loading, herbicide usage, and dike building (Katsuki et al. 2008). Freshwater systems are considered the main nutrient source for coastal lagoons (Flores-Verdugo et al. 1988, Forès et al. 1994, Boynton et al. 1996, Paerl 1997); however, oceanic nutrients (especially dissolved inorganic forms) also play an important role in 
determining the nature of the lagoon system. To date, relatively few studies have quantified oceanic nutrient sources to lagoons. In those studies, the impact of the oceanic source was masked by anthropogenic impact, except for one study of an undisturbed environment (Suga et al. 2011). By performing network analysis of nutrient cycling data for Tancada Lagoon, northeast Spain, Forès et al. (1994) suggested the relative importance of the increase in oceanic dissolved inorganic nitrogen (DIN) as a nitrogen source during seawater-dominated periods; however, they found that primary producers mainly depended on internal nitrogen recycling of terrestrial particulate matter from a rice field. Souza et al. (2003) described the heavily eutrophicated coastal lagoon system along the Brazilian coast acts as an effective sink for marine and terrestrial phosphorus and as a DIN source for coastal waters. Conversely, the mass balance study of Suga et al. (2011) suggested that nitrate supplied from the open ocean (Pacific Ocean) through the tidal inlet of Hichirippu Lagoon, northern Japan, was necessary to maintain the rich natural environment of the lagoon ecosystem during winter.

Recently, microphytobenthos (MPB) have been identified, along with phytoplankton, as important primary producers in coastal lagoons because of solar radiation reaching the sea floor (Anderson et al. 2003, Tyler et al. 2003), suspension of this microalgal community in the water column (de Jonge \& Beusekom 1992, de Jonge 1995), primary production that is sometimes higher than the local phytoplankton community (Montani et al. 2003, Ichimi et al. 2008), and adaptation to various nutrient concentrations from low (water column) to high (sediment pore water) conditions (Leynaert et al. 2009). The idea that the MPB community can function as a filter controlling dissolved nutrient flux at the sediment/water interface was presented $30 \mathrm{yr}$ ago (Henriksen et al. 1980, Sundbäck et al. 1991, Cahoon \& Cooke 1992, Cahoon 1999, Sundbäck et al. 2000, Sandwell et al. 2009, Komorita et al. 2010). Moreover, MPB activity may remove additional nutrients from the overlying water (Nilsson et al. 1991, Sundbäck et al. 2004, Sakamaki et al. 2006, Engelsen et al. 2008). Nedwell et al. (1999) hypothesized that benthic primary production may account for a higher proportion of nutrient uptake in oligotrophic estuaries with lower nutrient loads; however, this remains to be elucidated (Forster \& Kromkamp 2006).

Our study was conducted as part of a long-term project that aimed to quantify ecosystem dynamics from lower to higher trophic levels (including migra- tory birds) of a coastal lagoon (Hichirippu Lagoon). This lagoon has a rich natural environment and is designated as a wetland under the Ramsar Convention, Hokkaido, Japan. In this lagoon, MPB biomass (depth, $0.5 \mathrm{~cm}$ ) was approx. 80 times higher than phytoplankton biomass in the water column (depth, $1 \mathrm{~m}$ ) (Kajihara et al. 2010). In the tidal flats of this lagoon, excretions of the short-necked clam Tapes (Ruditapes) philippinarum may sustain primary production by MPB during summer, and nutrient supply may not be solely based on riverine inputs (Komorita et al. 2010). Nutrients supplied from outer regions of the lagoon are required to sustain production in the lagoon. Suga et al. (2011) suggested that nitrate imports from the Pacific Ocean through the tidal inlet are necessary to maintain the lagoon ecosystem during winter; however, there is no evidence of nutrient flow or a possible main sink in this lagoon. We assumed that dense MPB patches would take up these nutrients during winter and thereby sustain the lower trophic levels of the ecosystem.

We aimed to evaluate the pre-disturbance condition of the coastal lagoon ecosystem on water quality and to quantify nutrient flux and MPB. Semienclosed coastal lagoons allow ecological functions to be precisely evaluated by comparing these functions with the total nutrient input and nutrient dispersal by tidal exchange with the outer ocean (Hung \& Kuo 2002, Kohata et al. 2003, Komorita et al. 2010). Hichirippu Lagoon is connected with the Pacific Ocean by a narrow channel. We were able to measure the tidal exchange of water and nutrients by observing the flow rate and nutrient concentration in the channel. We conducted several field surveys to investigate spatio-temporal variations in the water quality of the lagoon, including inorganic nutrient concentrations. Because nitrogen (the deficient element) supplied through the tidal inlet was mainly $\mathrm{NO}_{3}+\mathrm{NO}_{2}-\mathrm{N}$ (Suga et al. 2011), we divided the seasonal variation period into supply and mineralization periods based on the $\mathrm{NO}_{3}+\mathrm{NO}_{2}-\mathrm{N}$ to DIN concentration ratio at the inlet. During the typical supply period (winter), a $24 \mathrm{~h}$ continuous survey was conducted to quantify nutrient flux from the open ocean and examine the possibility that MPB utilized the nutrients based on the standing stock. The annual nutrient budget was estimated based on the summer budget, determined in a recent study (Komorita et al. 2010). In the present study, we discuss the dynamics of nutrients and MPB (i.e. primary producers) in Hichirippu Lagoon, the importance of oceanic nutrient sources relative to other nutrient sources, and nutrient uptake by MPB in this lagoon. 


\section{MATERIALS AND METHODS}

\section{Study area}

Hichirippu Lagoon is shallow (mean water depth, ca. $1 \mathrm{~m}$ ) with brackish water and has an area of approx. $3.56 \mathrm{~km}^{2}$. It borders the Pacific Ocean along the eastern shore of Hokkaido Island, Japan $\left(43^{\circ} 05^{\prime} \mathrm{N}, 145^{\circ} 02^{\prime} \mathrm{E}\right.$; Fig. 1). Several small creeks empty into the north end of the lagoon, although they have a relatively small effect on water budget, ranging 0.9 to $8.0 \%$ of the total volume (Suga et al. 2011). During spring tide, the maximum tidal flow (predominant direction, northwest to southeast) reaches approx. $40 \mathrm{~cm} \mathrm{~s}^{-1}$ at the tidal inlet (Komorita et al. 2010) and ensures strong vertical mixing of the lagoon water (Suga et al. 2011). During extreme low tide, the exposed tidal flat area is approx. $0.19 \mathrm{~km}^{2}$ or $5.3 \%$ the lagoon area. In 1998 to 2004, 30 to 92 metric tons of Tapes (Ruditapes) philippinarum were harvested annually from these tidal flats (Chirippu Fishery Cooperative Union, unpubl. data). This study was conducted at 8 subtidal stations along the tidal flow center (Fig. 1).

\section{Sampling procedure}

From April 2004 to March 2008, long-term monitoring (monthly or bi-monthly) of seawater was performed during spring tide at 8 subtidal stations located along a transect line (Fig. 1) from the tidal inlet (Stn 0) to the innermost station (Stn 15) (Fig. 1). During seawater sampling, we monitored temperature, salinity, nutrient concentrations $\left(\mathrm{NH}_{4}-\mathrm{N}\right.$, $\mathrm{NO}_{3}+\mathrm{NO}_{2}-\mathrm{N}, \mathrm{PO}_{4}-\mathrm{P}$, and $\left.\mathrm{Si}(\mathrm{OH})_{4}-\mathrm{Si}\right)$, and chlorophyll $a(\mathrm{chl} a)$ concentrations in the floodwater at these stations. Hydrological measurements were performed vertically at $10 \mathrm{~cm}$ intervals using a conductivity, temperature, and depth profiler (YSI 556; YSI Hydrodata). Seawater samples (2 l) were collected from the surface as well as $10 \mathrm{~cm}$ above the sea floor (samples at Stn 0 were obtained from the surface only) using a motor pump (YPM-12; flow rate, $701 \mathrm{~min}^{-1}$; intake diameter, $105 \mathrm{~mm}$; Meiwa).

During the continuous survey conducted at Stn 0 (cross-sectional area, $240 \mathrm{~m}^{2}$; width, $80 \mathrm{~m}$; depth,


ples and vertical profiles of water temperature and salinity at $20 \mathrm{~cm}$ intervals once every hour before and after slack water as well as once every $2 \mathrm{~h}$ from 10:00 on 13 February to $10: 00$ on 14 February. At Stn T (Fig. 1), the tidal height was monitored using a tide indicator (RMD-5225A; Rigo) every 10 min before the continuous survey (from 7:00 on February 13).

Moreover, on 12 March 2008, we conducted a parallel field investigation of $\mathrm{chl}$ a concentrations in the surface sediments at 7 subtidal stations (excluding Stn 0). At each sampling station, sediment samples for chl a analysis were carefully collected using an Ekman-Birge grab sampler, which sampled a $20 \times$ $20 \mathrm{~cm}$ area to a depth of $20 \mathrm{~cm}$. The topmost $0.5 \mathrm{~cm}$ of



Fig. 1. Study area and location of sampling stations in a series of insets (following the arrows). In the map to the right, numbers and the letter ' $\mathrm{T}$ ' represent the sampling stations from the subtidal area and tidal level monitoring, respectively. Dashed line indicates the transect line. Open circles represent the sediment sampling stations 
the sediment was collected from 10 samples using an acrylic core tube (diameter, $3 \mathrm{~cm}$ ); the 10 samples were collected using the grab sampler. The top layer of the sediment cores was often brownish in color; thus, the disturbance effect of the sediment in the cores seemed to be negligible for subsequent measurements.

\section{Sample processing}

In the laboratory, seawater samples were filtered through glass fiber filters (GF/F; Whatman) into a Teflon beaker and then transferred to polystyrene test tubes. The filtrates were stored at $-20^{\circ} \mathrm{C}$ to prepare for nutrient analysis using an autoanalyser (QuAAtro; BL TEC; Strickland \& Parsons 1972). After filtration, chl a was extracted from the seawater samples using $90 \%$ acetone. Furthermore, chl $a$ in wet sediment samples was extracted from duplicate subsamples (ca. $0.5 \mathrm{~g}$ ) obtained using $90 \%$ acetone. After $24 \mathrm{~h}$ incubation in the dark at $-20^{\circ} \mathrm{C}$, the samples were sonicated for

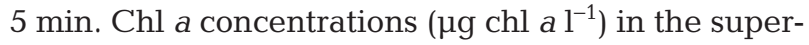
natants obtained before and after acidification with $1 \mathrm{~N} \mathrm{HCl}$ according to Lorenzen's (1967) method were analyzed using a fluorophotometer (Turner 10-AU-5, Turner Designs; Parsons et al. 1984). The dry weight (DW) of the sediment sample was substituted for the volume of pore water. Values thus expressed were corrected for porosity as measured by the water content in $\mu \mathrm{g}$ chl a g ${ }^{-1} \mathrm{DW}$. This water content was determined after drying a sediment sample (ca. $1 \mathrm{~g}$ ) at $60^{\circ} \mathrm{C}$ for $24 \mathrm{~h}$. In addition, the measurement of chl a concentration in the surface sediment (depth, $0.5 \mathrm{~cm}$ ) was expressed in relation to area ( $\mathrm{mg} \mathrm{chl} a \mathrm{~m}^{-2}$ ) by considering the bulk density of the sediment particles as $2.5 \mathrm{~g} \mathrm{~cm}^{-3}$ and spatio-temporal variations in pore water content (Montani et al. 2003).

\section{Data analysis}

The carbon contents (C/chl) of phytoplankton (Eppley 1968) and MPB (de Jonge 1980) were approx. 20 to -50 and 10 to 150 , respectively. Their elemental compositions $(\mathrm{C} / \mathrm{N})$ were 6.6 (Redfield et al. 1963) and 7.5 (Montani et al. 2003), respectively. The standing stock of nitrogen in the microalgae was obtained by multiplying these elemental ratios by the microalgal standing stock.

The current speed $\left(V_{i} \mathrm{~cm} \mathrm{~s}^{-1}\right)$ was estimated every 10 min at the tidal inlet (Stn 0$)$ according to $V(m)=$ $[T H(m)-T H(m+10)] \times(A) / S /(m \times 60 \mathrm{~s})$, where $V=$ current speed $\left(\mathrm{cm} \mathrm{s}^{-1}\right)$ at time ' $m$ ' (every $\left.10 \mathrm{~min}\right), T H$ = tidal height, $A=$ extent of the impact of the open ocean (half the lagoon area, $1.78 \mathrm{~km}^{2}$; Komorita et al. 2010), and $S=$ cross-sectional area $\left(240 \mathrm{~m}^{2}\right)$.

The current speed was shown as a $1 \mathrm{~h}$ running mean and converted from $\mathrm{cm} \mathrm{s}^{-1}$ to $\mathrm{m} \mathrm{h}^{-1}$ by multiplying with $100 \mathrm{~cm}, 60 \mathrm{~s}$, and $60 \mathrm{~min}$. Hourly nutrient flux $\left(F ;\right.$ mmol m$\left.~^{-2} \mathrm{~h}^{-1}\right)$ was expressed using $F(\mathrm{~h})=$ $C(\mathrm{~h}) \times(\mathrm{h})$, where $C=$ nutrient concentration $(\mathrm{mmol}$ $\mathrm{m}^{-3}$ ) converted from $\mu \mathrm{mol} \mathrm{l}^{-1}$ based on a continuous survey and $V(\mathrm{~h})=1 \mathrm{~h}$ running mean of the current velocity at every hour.

The freshwater input $\left(F W_{i} \times 10^{3} \mathrm{~m}^{3} \mathrm{~d}^{-1}\right)$ was estimated daily according to $F W(\mathrm{~d})=R F(\mathrm{~d}) \times C A$, where $R F=$ mean daily rainfall during $30 \mathrm{~d}$ before the continuous survey (data obtained from the Sakaki Meteorogical Agency Station, which is located approx. $10 \mathrm{~km}$ northwest of Hichirippu Lagoon), and $C A=$ water catchment area of $20.64 \mathrm{~km}^{2}$ (Hokkaido Institute of Environmental Sciences 2005).

\section{Statistical analysis}

Regression analysis was used to test the relationship between water temperature and the $\mathrm{NO}_{3}+$ $\mathrm{NO}_{2}-\mathrm{N}$ to DIN concentration ratio at the tidal inlet throughout the sampling period $(\mathrm{p}<0.05)$ using StatView (Hulinks). To identify the primary factors influencing variations in environmental parameters during the continuous survey (tidal height, current speed, water temperature, salinity, and nutrient concentration), we performed principal component analysis (PCA) of these data $(n=15)$ using SPSS 11.5.

\section{RESULTS}

\section{Seasonal variations in seawater}

Fig. 2 shows seasonal variations in sea surface temperature, salinity, and nutrient concentrations along the transect line from April 2004 to March 2008. Because the water column was strongly mixed vertically by the flood tide, the collected surface water samples were representative of the water column. On $\mathrm{Au}-$ gust 8,2006 , the water temperature peaked at $29.2^{\circ} \mathrm{C}$ at the innermost station (Stn 15) at a distance of

Fig. 2. Seasonal variation in (a) water temperature, (b) salinity, $(c, d, e, f)$ nutrient concentrations, and $(g, h)$ stoichiometric nutrient ratios in the surface seawater 

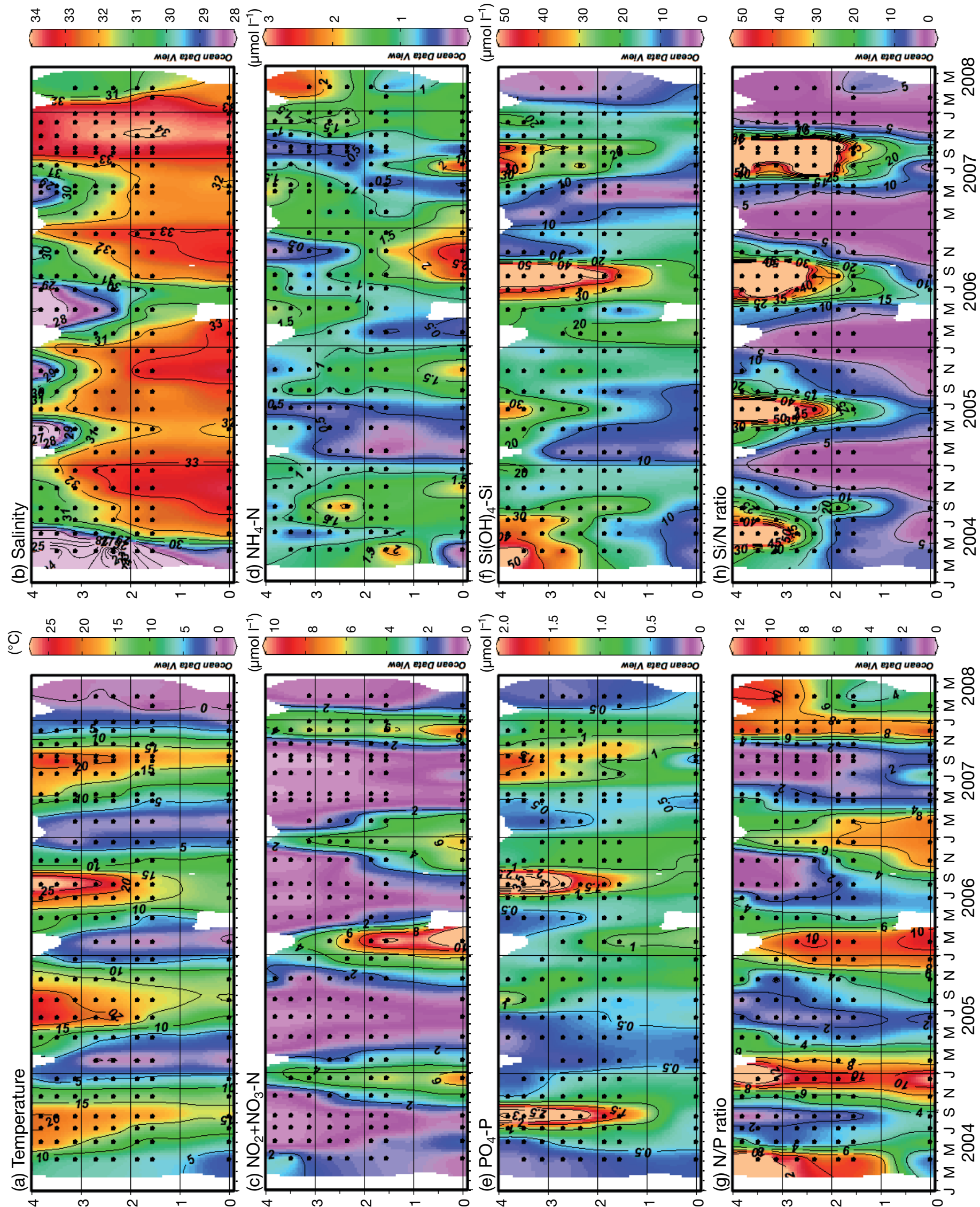

Distance from entrance of the lagoon $(\mathrm{km})$ 
$3.8 \mathrm{~km}$ from the tidal inlet. From August to September each year, this temperature rose above $20^{\circ} \mathrm{C}$ at a distance of 2 to $4 \mathrm{~km}$ from the tidal inlet (Fig. 2a). Smaller spatial temperature gradients were observed in winter (February or March) than in summer, and the lowest temperature was between $-1.3^{\circ} \mathrm{C}$ and $0.3^{\circ} \mathrm{C}$ each year. Conversely, salinity did not demonstrate a clear seasonal pattern and fluctuated between 27.5 and 34.1 throughout the sampling period (Fig. 2b).

$\mathrm{NO}_{3}+\mathrm{NO}_{2}-\mathrm{N}$ concentration around the tidal inlet showed a clear seasonal pattern, with low concentrations $\left(0.1\right.$ to $3.9 \mu \mathrm{mol} \mathrm{l^{-1 }}$ ) in April to September and high concentrations (6.3 to $11.6 \mu \mathrm{mol} \mathrm{l}^{-1}$ ) in December to March (Fig. 2c). Conversely, $\mathrm{NH}_{4}-\mathrm{N}$ concentration increased during summer (August to October) within a distance of $1.5 \mathrm{~km}$, and it reached 2.0 to $4.9 \mu \mathrm{mol} \mathrm{l}^{-1}$ during summer every year (Fig. 2d). During winter, the ocean appeared to be the main DIN source, which is in the form of $\mathrm{NO}_{3}+\mathrm{NO}_{2}-\mathrm{N}$.

$\mathrm{PO}_{4}-\mathrm{P}$ concentration exceeded $1 \mathrm{\mu mol}^{-1}$ from July to August and reached its highest value of $4.0 \mu \mathrm{mol}$ $1^{-1}$ at the innermost station on 19 August 2004 (Fig. 2e). The concentration fluctuated between 0.1 and $1.0 \mu \mathrm{mol} \mathrm{l}^{-1}$ on other occasions. Spatio-temporal variations in $\mathrm{Si}(\mathrm{OH})_{4}$-Si concentration were similar to those in $\mathrm{PO}_{4}-\mathrm{P}$ concentration; the highest value of $117 \mu_{\mathrm{mol} \mathrm{l}}{ }^{-1}$ was recorded at the innermost station on 8 August 2006 (Fig. 2f). During summer, a riverinederived source appeared to produce the majority of phosphate and silica.

DIN concentration increased sharply around the tidal inlet during winter (December to March; Fig. 2c). The molar ratios of $\mathrm{N}, \mathrm{P}$, and $\mathrm{Si}$ were distinctly different between winter (December to March: N/P, 9.1-12.5; Si/N, 1.4-3.9) near the tidal inlet and other seasons (April to November: N/P,
0.1-6.8; Si/N, 4.8-295) around the innermost part of the lagoon (Fig. 2g,h).

Fig. 3a shows seasonal variations in the $\mathrm{NO}_{3}+$ $\mathrm{NO}_{2}-\mathrm{N}$ to DIN concentration ratio at the tidal inlet. This ratio dropped below the mean value of 0.5 throughout the sampling period during summer (July to September). A significant correlation was observed between temperature and the concentration ratio at the tidal inlet (Fig. 3b; $r^{2}=0.56 ; p<0.0001 ; n=37$ ).

\section{Continuous survey}

During the continuous survey between 13 and 14 February 2008, there were 2 tidal cycles (low and high tides; Fig. 4a). The tidal level varied from $45.4 \mathrm{~cm}$ (15:00 on 13 February) to $147.9 \mathrm{~cm}$ (7:40 on 14 February) (Fig. 4a). The current speed reached its highest outflow $\left(-35.2 \mathrm{~cm} \mathrm{~s}^{-1}\right)$ at 11:10 on 13 February and inflow $\left(31.1 \mathrm{~cm} \mathrm{~s}^{-1}\right)$ at 5:40 on 14 February. Temperature varied from $-1.9^{\circ} \mathrm{C}$ to $-1.1^{\circ} \mathrm{C}$ and salinity from 31.8 to 33.6 (Fig. 4b). Temporal variations in $\mathrm{NO}_{3}+\mathrm{NO}_{2}-\mathrm{N}, \mathrm{PO}_{4}-\mathrm{P}$, and $\mathrm{Si}(\mathrm{OH})_{4}-\mathrm{Si}$ concentrations occurred with such variations in tidal height and peaked at $7.7,0.9$, and $15.8 \mu \mathrm{mol} \mathrm{l^{-1 }}$, respectively, during the high tide at 21:00 on 13 February (Fig. 4c,d). Conversely, temporal variations in $\mathrm{NH}_{4}-\mathrm{N}$ concentration showed a reverse pattern and ranged from 0.3 to $1.2 \mu \mathrm{mol} \mathrm{l}^{-1}$ (Fig. $4 \mathrm{c}$ ).

In the forward selection procedure of PCA, the rank next to the second PCA component was excluded from the eigenvalues and degrees of freedom. The variable explained $56.7 \%$ of the variance of the first PCA component (Table 1). This component seemed to reflect water moving with variations in tidal height, which showed the highest factor load-
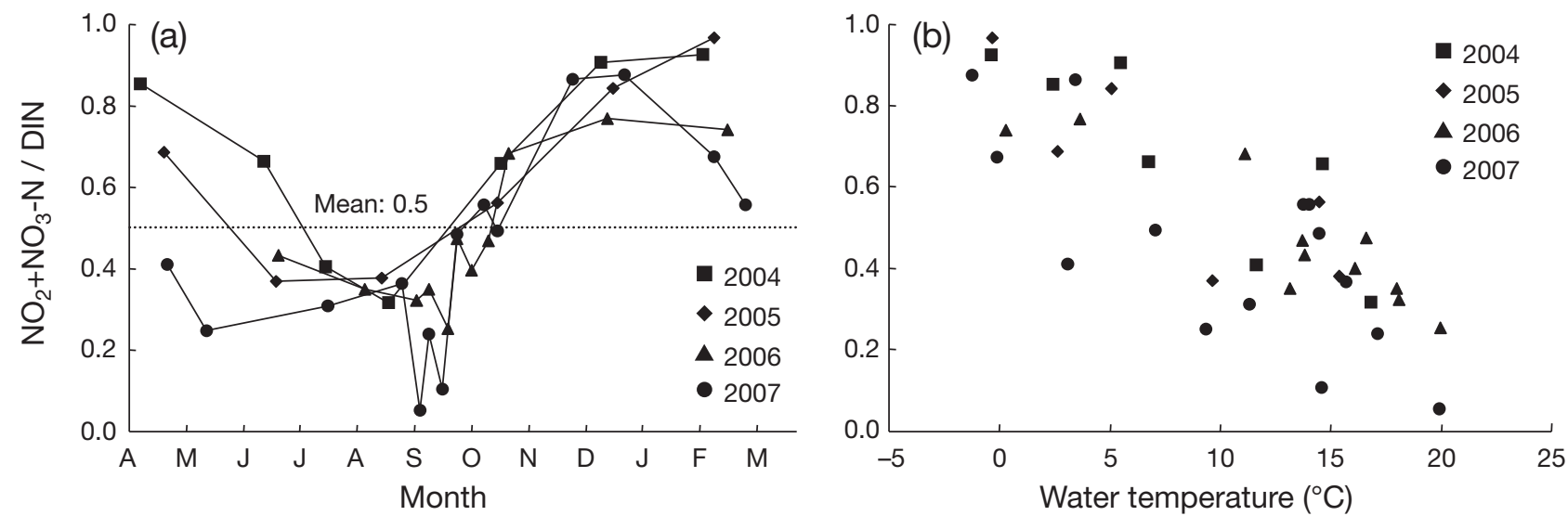

Fig. 3. (a) Seasonal variation in the concentration ratio of $\mathrm{NO}_{3}+\mathrm{NO}_{2}-\mathrm{N}$ to dissolved inorganic nitrogen (DIN) at Stn 0 . (b) Relationship between water temperature and the concentration ratio of $\mathrm{NO}_{3}+\mathrm{NO}_{2}-\mathrm{N} / \mathrm{DIN}$ 


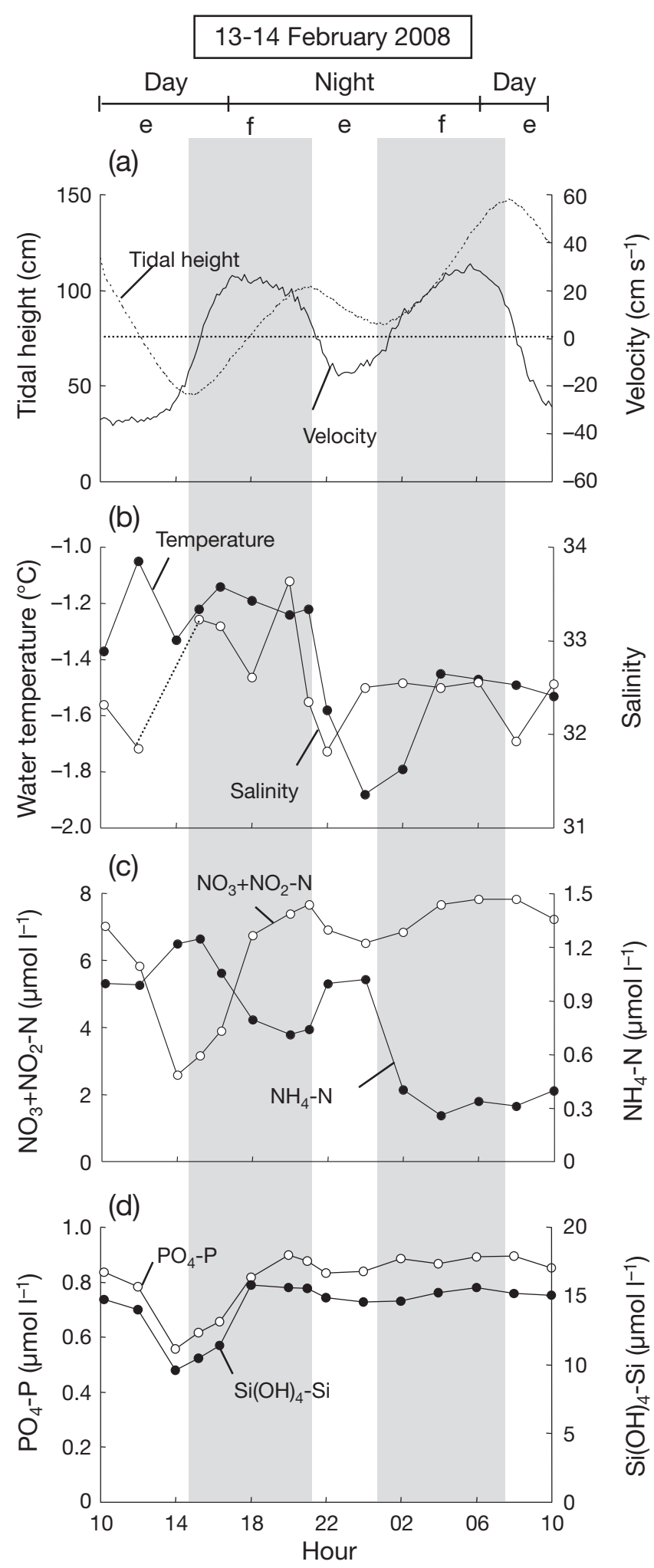

Fig. 4. (a) Tidal height and velocity, (b) temperature and salinity, and $(c, d)$ nutrient concentrations in seawater at the tidal inlet of the lagoon during a $24 \mathrm{~h}$ period on 13 and 14 February 2008. Grey and white areas represent flood ('f') and ebb ('e') tides, respectively
Table 1. Summary of results of principal component analysis using 8 variables. Significant correlation between each environmental variable and the 1st principal component (PC) are indicated with bold text: $\mathrm{p}<0.01$

\begin{tabular}{|lc|}
\hline & 1 st PC \\
\hline Eigenvalue & 4.53 \\
\% Variance & 56.7 \\
Factor loading of variables & \\
Tidal height & $\mathbf{0 . 8 6 8}$ \\
Velocity & 0.153 \\
Water temperature & -0.479 \\
Salinity & -0.453 \\
$\mathrm{NH}_{4}-\mathrm{N}$ & $\mathbf{- 0 . 7 7 7}$ \\
$\mathrm{NO}_{2}+\mathrm{NO}_{3}-\mathrm{N}$ & $\mathbf{0 . 9 7 7}$ \\
$\mathrm{PO}_{4}-\mathrm{P}$ & $\mathbf{0 . 9 6 1}$ \\
$\mathrm{Si}(\mathrm{OH})_{4}-\mathrm{Si}$ & $\mathbf{0 . 9 1 7}$ \\
\hline
\end{tabular}

ings $(\mathrm{r}=0.868, \mathrm{p}<0.01)$ of the physical components. This component strongly affected $\mathrm{NO}_{3}+\mathrm{NO}_{2}-\mathrm{N}(\mathrm{r}=$ $0.977, \mathrm{p}<0.01), \mathrm{PO}_{4}-\mathrm{P}(\mathrm{r}=0.961, \mathrm{p}<0.01)$, and $\mathrm{Si}(\mathrm{OH})_{4}$-Si concentrations $(\mathrm{r}=0.917 \mathrm{p}<0.01)$. Conversely, the factor $\mathrm{NH}_{4}-\mathrm{N}$ loading was negative $\left(\mathrm{NH}_{4}-\mathrm{N}: \mathrm{r}=-0.777, \mathrm{p}<0.01\right)$.

\section{Nutrient budget}

Table 2 shows the daily freshwater, seawater, and nutrient budgets in the continuous survey conducted at the tidal inlet during the supply period. Freshwater input was $0.16 \%$ of seawater influx through the tidal inlet. While the daily seawater budget showed a slight excess of exports over imports $\left(-78.3 \times 10^{3} \mathrm{~m}^{3}\right.$ $\mathrm{d}^{-1}$, the $\mathrm{NO}_{3}+\mathrm{NO}_{2}-\mathrm{N}, \mathrm{PO}_{4}-\mathrm{P}$, and $\mathrm{Si}(\mathrm{OH})_{4}$-Si budgets were $3.93 \mathrm{kmol} \mathrm{N} \mathrm{d}^{-1}, 0.32 \mathrm{kmol} \mathrm{P} \mathrm{d}^{-1}$, and $5.78 \mathrm{kmol}$ $\mathrm{Si} \mathrm{d}^{-1}$, respectively, and were higher than the outflow (Table 2; Fig. 4a,c,d). The molar budget ratio was $\mathrm{N}: \mathrm{P}: \mathrm{Si}=10.2: 1: 18.3$ (Table 2).

Seasonal variation in the $\mathrm{NO}_{3}+\mathrm{NO}_{2}-\mathrm{N}$ to DIN concentration ratio at the tidal inlet depended on water temperature (Fig. 3b). Here this ratio was used as an index of supply from the open ocean because $\mathrm{NO}_{3}-\mathrm{N}$ concentration in the surface layer depended on vertical mixing during winter (Kasai 2000; Fishery Research Agency 2008). We defined the months where the ratio dropped below the mean value of 0.5 at least once during the sampling period as the 'mineralization period' (April to October: $245 \mathrm{~d}$ ) and the other months as the 'supply period' (November to March: $120 \mathrm{~d}$ ).

Table 3 shows the integrated nutrient budget during the mineralization period (calculated on the basis of the results of Komorita et al. 2010), supply period, 
Table 2. Water and nutrient budgets at the entrance of the lagoon on 13 and 14 February 2008 and the elemental ratio of the budget. Negative values indicate export from the lagoon

\begin{tabular}{|lccccc|}
\hline & $\begin{array}{c}\text { Water } \\
\left(\times 10^{3} \mathrm{~m}^{3} \mathrm{~d}^{-1}\right)\end{array}$ & $\begin{array}{c}\mathrm{NO}_{3}+\mathrm{NO}_{2}-\mathrm{N} \\
\left(\mathrm{kmol} \mathrm{d}^{-1}\right)\end{array}$ & $\begin{array}{c}\mathrm{NH}_{4}-\mathrm{N} \\
\left(\mathrm{kmol} \mathrm{d}^{-1}\right)\end{array}$ & $\begin{array}{c}\mathrm{PO}_{4}-\mathrm{P} \\
\left(\mathrm{kmol} \mathrm{d}^{-1}\right)\end{array}$ & $\begin{array}{c}\mathrm{Si}(\mathrm{OH})_{4}-\mathrm{Si} \\
\left(\mathrm{kmol} \mathrm{d}^{-1}\right)\end{array}$ \\
\hline Freshwater & 3.44 & & & & \\
Influx & 2129 & 13.3 & 0.98 & 1.58 & 28.2 \\
Efflux & -2207 & -9.33 & -1.67 & -1.26 & -22.4 \\
Budget & -78.3 & 3.93 & -0.68 & 0.32 & 5.78 \\
N:P:Si & & \multicolumn{4}{c}{$10.2: 1: 18.3$} \\
\hline
\end{tabular}

Table 3. Integrated nutrient budget over each period (see details in 'Results: Nutrient budget'). Nutrient budget during mineralization period was calculated based on the value of Komorita et al. (2010). Negative values indicate export from the lagoon

\begin{tabular}{|lccccc|}
\hline \multirow{2}{*}{ Period } & Duration & \multicolumn{4}{c|}{ Nutrient budget (kmol per period) } \\
& $(\mathrm{d})$ & $\mathrm{NO}_{3}+\mathrm{NO}_{2}-\mathrm{N}$ & $\mathrm{NH}_{4}-\mathrm{N}$ & $\mathrm{PO}_{4}-\mathrm{P}$ & $\mathrm{Si}(\mathrm{OH})_{4}-\mathrm{Si}$ \\
\hline Mineralization & 245 & 35 & -166 & 14 & -4350 \\
Supply & 120 & 471 & -82 & 38 & 694 \\
Annual & 365 & 506 & -248 & 52 & -3660 \\
\hline
\end{tabular}

and 1 yr. The integrated $\mathrm{DIN}, \mathrm{PO}_{4}-\mathrm{P}$, and $\mathrm{Si}(\mathrm{OH})_{4}-\mathrm{Si}$ budgets during the supply period were positive values, i.e. $389 \mathrm{kmol} \mathrm{N} 120 \mathrm{~d}^{-1}\left(=471 \mathrm{kmol}\left(\mathrm{NO}_{3}+\mathrm{NO}_{2}\right.\right.$ N) $120 \mathrm{~d}^{-1}$ plus $-82.1 \mathrm{kmol}\left(\mathrm{NH}_{4}-\mathrm{N}\right) 120 \mathrm{~d}^{-1}$; Table 3), $38.0 \mathrm{kmol} \mathrm{P} 120 \mathrm{~d}^{-1}$, and $694 \mathrm{kmol} \mathrm{Si} 120 \mathrm{~d}^{-1}$, respectively. The integrated DIN and $\mathrm{Si}(\mathrm{OH})_{4}$-Si budgets during the mineralization period were negative values, i.e. $-131 \mathrm{kmol} \mathrm{N} 240 \mathrm{~d}^{-1}$ and $-4350 \mathrm{kmol} \mathrm{Si} 240$ $\mathrm{d}^{-1}$, respectively, in contrast to the integrated $\mathrm{PO}_{4}-\mathrm{P}$ $\left(14 \mathrm{kmol} \mathrm{P} 240 \mathrm{~d}^{-1}\right)$ budget. The annual DIN and $\mathrm{PO}_{4}{ }^{-}$ $\mathrm{P}$ budgets were positive values, i.e. $258 \mathrm{kmol} \mathrm{N} \mathrm{yr}^{-1}$ and $52 \mathrm{kmol} \mathrm{P} \mathrm{yr}^{-1}$, respectively, whereas the annual $\mathrm{Si}(\mathrm{OH})_{4}$-Si budget was a significantly negative value

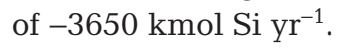

\section{Microalgal standing stocks}

In March 2008, the mean biomass per unit area of MPB in the surface sediment (depth, $0.5 \mathrm{~cm} ; 96.7 \pm$

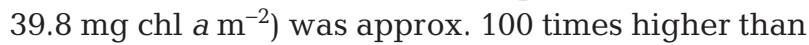
that of phytoplankton in the water column (depth,

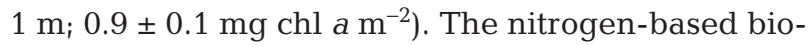
mass of MPB and phytoplankton was 10.8 to $161 \mathrm{mmol} \mathrm{N} \mathrm{m}^{-2}$ and 0.227 to $0.569 \mathrm{mmol} \mathrm{N} \mathrm{m}^{-2}$, respectively. The total amount of nitrogen in the lagoon was 38.3 to $574 \mathrm{kmol} \mathrm{N}$ for MPB and 0.81 to $2.02 \mathrm{kmol} \mathrm{N}$ for phytoplankton, multiplied by the lagoon area $\left(3.56 \mathrm{~km}^{2}\right)$.

\section{DISCUSSION}

\section{External nutrient supply}

Comparison of the N/P and $\mathrm{Si} / \mathrm{N}$ ratios of long-term samples with the Redfield ratio $(\mathrm{N} / \mathrm{P}=16 ; \mathrm{Si} / \mathrm{N}=1$; Redfield et al. 1963) clearly suggested nitrogen deficiency in this lagoon (Fig. 2g,h) (Komorita et al. 2010, Suga et al. 2011). During winter, a high $\mathrm{NO}_{3}+\mathrm{NO}_{2}-\mathrm{N}$ concentration (6.3 to $11.6 \mu \mathrm{mol} \mathrm{l}^{-1}$ ) near the tidal inlet (Fig. 2c) and input through this inlet (Table 2) is important for the lagoon ecosystem. At the sampling station approx. $10 \mathrm{~km}$ offshore from this lagoon $\left(42^{\circ} 50^{\prime} \mathrm{N}, 144^{\circ} 50^{\prime} \mathrm{E}\right), \mathrm{NO}_{3}-\mathrm{N}$ concentration in the surface layer increased between 15 and $20 \mu \mathrm{mol} \mathrm{l}^{-1}$ because of strong vertical mixing throughout the approx. $200 \mathrm{~m}$ depth during winter (January to March). The concentration dropped below measurable limits after a spring phytoplankton bloom in April (Kasai 2000; data from a-line database ${ }^{1}$ ). Thus, the open ocean appeared to be the major $\mathrm{NO}_{3}+\mathrm{NO}_{2}-\mathrm{N}$ source in this study area during winter, and the annual DIN budget from the tidal inlet was estimated to be $258 \mathrm{kmol} \mathrm{N}$ $\mathrm{yr}^{-1}\left(\mathrm{NO}_{3}+\mathrm{NO}_{2}-\mathrm{N}\right.$ plus $\mathrm{NH}_{4}-\mathrm{N}$, Table 3$)$.

Other nutrient sources for coastal lagoon systems include riverine (Nedwell et al. 1999, Mann 2000), groundwater (Paerl 1997, Nedwell et al. 1999), and atmospheric nutrient deposition (Paerl 1997). In this study area, freshwater input from riverine systems was estimated to be $3.44 \times 10^{3} \mathrm{~m}^{3} \mathrm{~d}^{-1}$ during the supply period (Table 2 ) and accounted for $0.16 \%$ of seawater inflow. These results, which conformed to a recent study, showed that freshwater has a relatively small effect on the water budget, ranging from 0.9 to $8.0 \%$ of the total volume in this lagoon (Suga et al. 2011) and suggested that the riverine input of DIN was a minor contributor to the ecosystem only during summer (Komorita et al. 2010). Because high $\mathrm{NO}_{3}-\mathrm{N}$ concentration in the groundwater declines sharply as a result of denitrification before discharge (Onodera et al. 2007), it is highly unlikely that groundwater was the primary nitrogen source in this lagoon.

In terms of atmospheric deposition, Nedwell et al. (1999) indicated that direct inputs to an estuary are

\footnotetext{
1http://fra.affrc.go.jp/a-line; Fishery Research Agency, accessed 5 December 2008
} 
small compared with the fluvial component. Global atmospheric deposition of nitrogen in 1890 (non-polluted area alone) and 1990 (non-polluted and polluted areas) was estimated to be 17 and $27 \mathrm{Tg} \mathrm{N} \mathrm{yr}^{-1}$, respectively (Galloway \& Cowling 2002). If we assume these values to be atmospheric nitrogen deposition, the average flux was 6.5 and $10.4 \mu \mathrm{mol} \mathrm{N}$ $\mathrm{m}^{-2} \mathrm{yr}^{-1}$ divided by the surface area of the planet (ca. $5.1 \times 10^{14} \mathrm{~m}^{2}$ ). Based on the values obtained by Galloway and Cowling (2002), atmospheric nitrogen deposition flux in this lagoon, isolated from the highly populated areas, was estimated to be between $0.02 \mathrm{kmol} \mathrm{N}\left(3.56 \mathrm{~km}^{-2}\right) \mathrm{d}^{-1}$ and $0.04 \mathrm{kmol} \mathrm{N}(3.56$ $\left.\mathrm{km}^{-2}\right) \mathrm{d}^{-1}$. In the present study, $\mathrm{NO}_{3}+\mathrm{NO}_{2}-\mathrm{N}$ input through the tidal inlet was $3.93 \mathrm{kmol} \mathrm{N} \mathrm{d}^{-1}$ (Table 2). Thus, the contribution of atmospheric nitrogen deposition is less than $2 \%$ of the supply from the open ocean during winter in this study area.

In addition to the supply of dissolved inorganic nutrients, several studies suggested that the coastal area receives a considerable amount of particulate organic matter (POM) from outside the area (Cadée 1980, Forès et al. 1994, Camacho-Ibar et al. 2003, Kohata et al. 2003, Barros et al. 2010). The present study indicated that the impact of nutrient flow from the open ocean is somewhat underestimated because we neglected the effect of POM supplied from the neighboring ocean.

\section{Nutrient budget and nutrient uptake by MPB during winter}

Microalgal growth rates are positively affected by water temperature (Goldman \& Carpenter 1974, Rose \& Caron 2007). However, the growth rate of planktonic diatom species (Thalassiosira nordenskioeldii and Detonula confervacea) isolated from low temperature environments (Saroma Lagoon, Hokkaido, Japan) reaches 0.3 to $0.4 \mathrm{~d}^{-1}$ at $-1.8^{\circ} \mathrm{C}$ (Suzuki \& Takahashi 1995), similar to that during the supply period of this study $\left(-1.9^{\circ} \mathrm{C}\right.$ to $-1.1^{\circ} \mathrm{C}$; Fig. 4b). Thus, biophilic elemental budgets (Table 2; Fig. 4a,c,d) during the continuous survey were a result of nutrient uptake by microalgae that are adapted to the low temperature.

Based on this interpretation, we estimated the amount of organic nitrogen represented by MPB and phytoplankton in this lagoon. Assuming that MPB in the surface sediment (depth, $0.5 \mathrm{~cm}$ ) used all $\mathrm{NO}_{3}+\mathrm{NO}_{2}-\mathrm{N}$ input $\left(3.93 \mathrm{kmol} \mathrm{N} \mathrm{d}{ }^{-1}\right.$ ), the temporal division rate $\left(\mathrm{NO}_{3}+\mathrm{NO}_{2}-\mathrm{N}\right.$ uptake/total amount of MPB) of MPB would be 0.01 to $0.10 \mathrm{~d}^{-1}$. MPB appears to be able to achieve this rate, which is consistent as per report by Suzuki and Takahashi (1995). Conversely, assuming that phytoplankton in the water column used all $\mathrm{NO}_{3}+\mathrm{NO}_{2}-\mathrm{N}$ input, the temporal division rate would be 1.94 to $4.85 \mathrm{~d}^{-1}$. The reported phytoplankton division rates under low temperatures $\left(-1.8^{\circ} \mathrm{C}\right)$ are at least one-seventh of the abovementioned range $\left(0.3\right.$ to $\left.0.4 \mathrm{~d}^{-1}\right)$; thus, phytoplankton alone may not be responsible for the observed levels of $\mathrm{NO}_{3}+\mathrm{NO}_{2}-\mathrm{N}$ uptake in this lagoon.

As observed in this lagoon during winter, denitrification may be performed by many heterotrophic anaerobic bacteria under relatively high $\mathrm{NO}_{3}+\mathrm{NO}_{2}$ $\mathrm{N}$ concentrations (Nielsen et al. 1995, Ogilvie et al. 1997, Trimmer et al. 1998, Sundbäck et al. 2000). $\mathrm{NO}_{3}-\mathrm{N}$ concentration is identified as one of the main factors controlling denitrification (Seitzinger 1988, Rysgaard et al. 1995), in addition to water temperature (Trimmer et al. 1998). According to Deek et al. (2011), the denitrification rate appeared to increase linearly with nitrate (denitrification $\left[\mu \mathrm{mol} \mathrm{m}^{-2} \mathrm{~h}^{-1}\right]=$ 1.01 or $0.39 \times$ nitrate $\left[\mu \mathrm{mol} \mathrm{l}^{-1}\right]+1.07$ or 0.01 , in fine or coarse sand stations, respectively) availability, which was relatively low $\left(<30 \mu \mathrm{mol} \mathrm{l}^{-1}\right)$ and restricted to winter (water temperature was 1 to $8^{\circ} \mathrm{C}$ ). If we calculate the denitrification rate using these equations and mean $\mathrm{NO}_{3}+\mathrm{NO}_{2}-\mathrm{N}$ concentration of $6.4 \mu \mathrm{mol} \mathrm{l} \mathrm{l}^{-1}$ obtained during the continuous survey, the denitrification rate in this study area was 0.06 to $0.181 \mathrm{mmol}$ $\mathrm{N} \mathrm{m}^{-2} \mathrm{~d}^{-1}$, and the total denitrification rate was estimated to be 0.21 to $0.64 \mathrm{kmol} \mathrm{N} \mathrm{d}^{-1}$ multiplied by the lagoon area $\left(3.56 \mathrm{~km}^{2}\right)$. The contribution of denitrification would be $16 \%$ of the supply from the open ocean (3.93 $\mathrm{kmol} \mathrm{N} \mathrm{d}^{-1}$; Table 2) during winter in this study area. However, other nutrients were also supplied through the tidal inlet during the continuous survey (Table 2), and the molar ratio of the nutrient budget during the supply period (N:P:Si = 10.2:1:18.3; Table 2) approached that of MPB (10.1:1:17.8; Montani et al. 2003). Thus, MPB appears to be the major nutrient sink during winter, and we assumed that denitrification contributed to the nutrient budget next to the microalgal communities.

\section{CONCLUSION}

During winter, the ocean was the main DIN source, a deficient nutrient, in this lagoon. It appears that MPB fixed the oceanic nutrient during the supply period, and the main nutrient sink seemed to be MPB. Although further studies of the nutrient budget from several sources and fine time scales (monthly or 
bi-weekly), in addition to those of POM, are needed to determine the precision budgets in this lagoon, the annual nitrogen budget of this study was estimated to be $258 \mathrm{kmol} \mathrm{N} \mathrm{yr}^{-1}$, which mainly depended on oceanic DIN fixed by MPB during winter.

Acknowledgements. Sampling was conducted with the cooperation of the Chirippu Fishery Cooperative Union. We express our thanks to Dr. I. Kudo at Hokkadio University, Dr. V. N. de Jonge at Hull University, and 2 anonymous reviewers for their constructive comments. This study was funded by MEXT Grants-in-Aid-for Scientific Research (A) Project No. 22380102 (to S.M.) and (B) Project No. 15201001 (to S.M.).

\section{LITERATURE CITED}

Anderson IC, McGlathery KJ, Tyler AC (2003) Microbial mediation of 'reactive' nitrogen transformations in a temperate lagoon. Mar Ecol Prog Ser 246:73-84

> Barros GV, Martinelli LA, Novais TMO, Ometto JPHG, Zuppi GM (2010) Stable isotopes of bulk organic matter to trace carbon and nitrogen dynamics in an estuarine ecosystem in Babitonga Bay (Santa Catarina, Brazil). Sci Total Environ 408:2226-2232

- Boynton WR, Hagy JD, Murray L, Stoles C, Kemp WM (1996) A comparative analysis of eutrophication patterns in a temperate coastal lagoon. Estuaries 19:408-421

Cadée GC (1980) Reappraisal of the production and import of organic matter in the western Wadden Sea. Neth J Sea Res 14:305-322

Cahoon LB (1999) The role of benthic microalgae in neritic ecosystems. Oceanogr Mar Biol Annu Rev 37:47-86

> Cahoon LB, Cooke JE (1992) Benthic microalgal production in Onslow Bay, North Carolina, USA. Mar Ecol Prog Ser 84:185-196

Camacho-Ibar VM, Carriquiry JD, Smith SV (2003) Nonconservative $\mathrm{P}$ and $\mathrm{N}$ fluxes and net ecosystem production in San Quintin Bay, Mexico. Estuaries 26:1220-1237

de Jonge VN (1980) Fluctuations in the organic carbon to chlorophyll a ratios for estuarine benthic diatom populations. Mar Ecol Prog Ser 2:345-353

de Jonge VN (1995) Wind-driven tidal and annual gross transports of mud and microphytobenthos in the Ems estuary, and its importance for the ecosystem. In: Dyer $\mathrm{KR}$, Orth RJ (eds) Changes in fluxes in estuaries. Olsen \& Olsen, Fredensborg, p 29-40

de Jonge VN, van Beusekom JEE (1992) Contribution of resuspended microphytobenthos to total phytoplankton in the Ems estuary and its possible role for grazers. Neth J Sea Res 30:91-105

> Deek A, Emeis K, van Beusekom J (2011) Nitrogen removal in coastal sediments of the German Wadden Sea. Biogeochem doi:10.1007/s10533-011-9611-1

Engelsen A, Hulth S, Pihl L, Sundbäck K (2008) Benthic trophic status and nutrient fluxes in shallow-water sediments. Estuar Coast Shelf Sci 78:783-795

Eppley RW (1968) An incubation method for estimating the carbon content of phytoplankton in natural samples. Limnol Oceanogr 13:574-582

> Flores-Verdugo FJ, Day JW, Mee L, Briseño-Dueñas R (1988) Phytoplankton production and seasonal biomass variation of seagrass, Ruppia maritima L., in a tropical
Mexican lagoon with an ephemeral inlet. Estuaries 11: $51-56$

Forès E, Christian RR, Comín FA, Menendez M (1994) Network analysis on nitrogen in a coastal lagoon. Mar Ecol Prog Ser 106:283-290

Forster RM, Kromkamp JC (2006) Estimating benthic primary production: scaling up from point measurements to the whole estuary. In: Kromkamp JC, de Brouwer JFC, Blanchard GF, Forster RM, Créach V (eds) Functioning of microphytobenthos in estuaries. Verh K Akad Afd Natuurkd Tweede Reeks Deel 103:109-120

> Galloway JN, Cowling EB (2002) Reactive nitrogen and the world: 200 years of change. Ambio 31:64-71

Goldman JC, Carpenter EJ (1974) A kinetic approach to the effect of temperature on algal growth. Limnol Oceanogr 19:756-766

Henriksen K, Hansen JI, Blackburn TH (1980) The influence of benthic infauna on exchange rates of inorganic nitrogen between sediment and water. Ophelia 1:249-256

Hokkaido Institute of Environmental Sciences (2005) Lakes and marshes in Hokkaido. National Institute for Environmental Science Press, 112 (in Japanese)

> Hung J, Kuo F (2002) Temporal variability of carbon and nutrient budgets from a trophic lagoon in Chiku, southwestern Taiwan. Estuar Coast Shelf Sci 54:887-900

Ichimi K, Yamashita H, Sawayama M, Tada K, Montani S (2008) Growth potential of the benthic microalgal community inhabiting the Shinkawa-Kasugagawa estuary in the Seto Inland Sea, Japan. Bull Plankton Soc Japan 55: 1-8 (in Japanese, with English abstract)

Kajihara R, Komorita T, Hamada A, Shibanuma S, Yamada T, Montani S (2010) Possibility of direct utilization of seagrass and algae as main food resources by small gastropod, Lacuna decorata, in a subarctic lagoon, Hichirippu, eastern Hokkaido, Japan with stable isotope evidences of carbon and nitrogen. Plankton Benthos Res 5:90-97

Kasai H (2000) Seasonal change of nutrients and primary production in the Oyashio region. Bull Plankton Soc Japan 47:116-118 (in Japanese with English abstract)

Katsuki K, Miyamoto Y, Yamada K, Takata H and others (2008) Eutrophication-induced changes in Lake Nakaumi, southwest Japan. J Paleolimnol 40:1115-1125

Kemp WM, Boynton WR, Adolf JE, Boesch DF and others (2005) Eutrophication of Chesapeake Bay: historical trends and ecological interactions. Mar Ecol Prog Ser 303:1-29

Kjerfve B (1986) Comparative oceanography of coastal lagoon. In: Wolfe DA (ed) Estuarine variability. Academic Press, New York, NY, p 63-81

Knoppers B, Kjerfve B, Carmouze JP (1991) Trophic state and water turn-over in six choked coastal lagoons in Brazil. Biogeochemistry 14:149-166

Kohata K, Hiwatari T, Hagiwara T (2003) Natural waterpurification system observed in a shallow coastal lagoon: Matsukawa-ura, Japan. Mar Pollut Bull 47:148-154

Komorita T, Kajihara R, Tsutsumi H, Shibanuma S, Yamada T, Higaki N, Montani S (2010) Reevaluation of the nutrient mineralization process by infaunal bivalves (Ruditapes philippinarum) in a shallow lagoon in Hokkaido, Japan. J Exp Mar Biol Ecol 383:8-16

> Leynaert A, Longphuirt SN, Claquin P, Chauvaud L, Ragueneau O (2009) No limit? The multiphasic uptake of silicic acid by benthic diatoms. Limnol Oceanogr 54:571-576

Lorenzen CJ (1967) Determination of chlorophyll and 
pheopigments: spectrophotometric equations. Limnol Oceanogr 12:343-346

Mann KH (2000) Estuarine planktonic system. In: Mann $\mathrm{KH}$ (ed) Ecology of coastal waters: with implications for management, 2nd edn. Blackwell Science, Halifax, p 94-117

Montani S, Magni P, Abe N (2003) Seasonal and interannual patterns of intertidal microphytobenthos in combination with laboratory and areal production estimates. Mar Ecol Prog Ser 249:79-91

Nedwell DB, Jickells TD, Trimmer M, Sanders R (1999) Nutrients in estuaries. Adv Ecol Res 29:43-92

> Nielsen K, Neilsen LP, Rasmussen P (1995) Estuarine nitrogen retention independently estimated by the denitrification rate and mass balance methods: a study of Norsminde Fjord, Denmark. Mar Ecol Prog Ser 119: $275-283$

Nilsson P, Jonsson B, Swanberg IL, Sundbäck K (1991) Response of a marine shallow-water sediment system to an increased load of inorganic nutrients. Mar Ecol Prog Ser 71:275-290

Ogilvie B, Nedwell DB, Harrison RM, Robinson A, Sage A (1997) High nitrate, muddy estuaries sinks: the nitrogen budget of the River Colne estuary (United Kingdom). Mar Ecol Prog Ser 150:217-228

Onodera S, Saito M, Hayashi M, Sawano M (2007) Nutrient dynamics with groundwater-seawater interactions in a beach slope of a steep island, western Japan. IAHS Publ 312:150-158

Paerl HW (1997) Coastal eutrophication and harmful harmful algal bloom: importance of atmospheric deposition and groundwaters as 'new' nitrogen and other nutrient sources. Limnol Oceanogr 42:1154-1165

Parsons TR, Maita Y, Lalli CM (1984) A manual of chemical and biological methods for seawater analysis. Pergamon Press, Oxford

Redfield AC, Ketchum BH, Richards FA (1963) The influence of organisms on the composition of sea-water. In: Hill MN (ed) The Sea. Wiley, New York, NY, p 26-77

Rose JM, Caron DA (2007) Does low temperature constrain the growth rates of heterotrophic protists? Evidence and implication for algal bloom in cold waters. Limnol Oceanogr 52:886-895

Ruiz-Fernández AC, Frignani M, Tesi T, Bojórquez-Leyva H, Bellucci LG, Páez-Osuna F (2007) Recent sedimentary history of organic matter and nutrient accumulation in the Ohuira Lagoon, Northwestern Mexico. Arch Environ Contam Toxicol 53:159-167

Rysgaard S, Christensen PB, Nielsen LP (1995) Seasonal variation in nitrification and denitrification in estuarine sediment colonized by benthic microalgae and bioturbating infauna. Mar Ecol Prog Ser 126:111-121

Sakamaki T, Nishimura O, Sudo R (2006) Tidal time-scale variation in nutrient flux across the sediment-water interface of an estuarine tidal flat. Estuar Coast Shelf Sci 67: $653-663$

Sandwell DR, Pilditch CA, Lohrer AM (2009) Density dependent effects of an infaunal suspension-feeding bivalve (Austrovenus stutchburyi) on sandflat nutrient fluxes and microphytobenthic productivity. J Exp Mar Biol Ecol 373: $16-25$

> Seitzinger SP (1988) Denitrification in freshwater and coastal marine ecosystems: ecological and geochemical significance. Limnol Oceanogr 33:702-724

> Souza MFL, Kjerfve B, Knoppers B, de Souza WFL, Damasceno RN (2003) Nutrient budgets and trophic state in a hypersaline coastal lagoon: Lagoa de Araruama, Brazil. Estuar Coast Shelf Sci 57:843-858

Strickland JDH, Parsons TR (1972) A practical handbook of seawater analysis. Fisheries Research Board of Canada, Ottawa

Suga N, Shibanuma S, Yamada T, Higaki N, Montani S (2011) Spatial-temporal distribution and origin of nutrients in the subarctic lagoon of Hichirippu (Hokkaido, Japan). Oceanography in Japan 20:19-36 (in Japanese with English abstract)

Sundbäck K, Enoksson V, Granéli W, Pettersson K (1991) Influence of sublittoral microphytobenthos on the oxygen and nutrient flux between sediment and water: a laboratory continuous-flow study. Mar Ecol Prog Ser 74: 263-279

Sundbäck K, Miles A, Göransson E (2000) Nitrogen fluxes, denitrification and the role of microphytobenthos in microtidal shallow-water sediments: an annual study. Mar Ecol Prog Ser 200:59-76

> Sundbäck K, Linares F, Larson F, Wulff A (2004) Benthic nitrogen fluxes along a depth gradient in a microtidal fjord: the role of denitrification and microphytobenthos. Limnol Oceanogr 49:1095-1107

Suzuki Y, Takahashi M (1995) Growth responses of several diatom species isolation from various environments to temperature. Eur J Phycol 31:880-888

> Trimmer M, Nedwell DB, Sinyer DB, Malcolm SJ (1998) Nitrogen fluxes through the lower estuary of the river Great Ouse, England: the role of the bottom sediments. Mar Ecol Prog Ser 163:109-124

Tyler AC, McGlathery KJ, Anderson IC (2003) Benthic algae control sediment-water fluxes of organic and inorganic nitrogen compounds in a temperate estuary. Limnol Oceanogr 48:2125-2137

Submitted: April 7, 2011; Accepted: October 21, 2011

Proofs received from author(s): January 24, 2012
Editorial responsibility: Matthias Seaman,

Oldendorf/Luhe, Germany 